\title{
Covidaemia and its implications
}

\section{Anushri Soni, Tanya Manish Arickatt, Akshita Bhalerao, Santosh Kondekar*}

\author{
Department of Paediatrics, Topiwala National Medical College and B.Y.L. Nair Charitable Hospital, Mumbai, \\ Maharashtra, India
}

Received: 06 October 2020

Accepted: 13 November 2020

\author{
*Correspondence: \\ Dr. Santosh Kondekar, \\ E-mail: writetodoctor@gmail.com
}

Copyright: (c) the author(s), publisher and licensee Medip Academy. This is an open-access article distributed under the terms of the Creative Commons Attribution Non-Commercial License, which permits unrestricted non-commercial use, distribution, and reproduction in any medium, provided the original work is properly cited.

\begin{abstract}
Coronavirus disease 2019 (COVID-19) pandemic has taught many lessons to the medical fraternity. Academicians and the general population have been through phases of anxiety, panic, and trail and errors. The growing assumption at the onset of the pandemic that COVID infection may spread by blood has not found its roots deep enough for any clinical consequences. As all the symptoms of COVID relate to its local invasion at the alveolar level and its immunological sequelae, this article discusses the possibilities with the research available over the last 10 months. So far, the plasma viral load detected by reverse transcriptase polymerase chain reaction (RT-PCR) seems immaterial in comparison to the viral concentration from nasopharyngeal swabs. So the recommendations to prefer caesarean section for positive mothers, deferring blood donations by COVID patients, frequent antigen testing from blood serum and body fluids like breast milk or amniotic fluid, may really need to be given a second thought. Also, this article concludes about giving up the panic around the viremia-related possibility of vertical transmission from mother to fetus and other clinical implications of testing of blood for the same. This will help in saving the resources heavily to be used only selectively. Newborns in neonatal intensive care unit (NICU) may be permitted to be handled without gloves and using simple practices of handwashing, saving further resources and reducing neonatal infections.
\end{abstract}

Keywords: Viraemia, Vertical transmission, COVID-19, Neonatal COVID, RT-PCR

\section{INTRODUCTION}

A novel beta-coronavirus, severe acute respiratory syndrome coronavirus-2 (SARS-CoV-2) that originated in Wuhan, China in December 2019 is responsible for the recent outbreak of pneumonia cases that the World Health Organization (WHO) proclaimed as the global coronavirus disease 2019 (COVID-19) pandemic on 11th March, 2020. With its spread spanning across 213 countries and territories, affecting over 34.2 million people to date and, taking the lives of over a million, there is a rising need to amplify the diagnostic testing and understand this virus better to control the spread. Also, the practice of doing newborn reverse transcriptase polymerase chain reaction (RT-PCR) need to be discontinued as covidaemia (SARSCoV-2), is also rare in amniotic fluid. This will also help save resources for better use.
As per current Centers for Disease Control and Prevention (CDC) guidelines, RT-PCR of an upper respiratory specimen (nasopharyngeal specimen, oropharyngeal specimen, mid-turbinate nasal swab, nasal swab, or a nasopharyngeal/nasal wash/aspirate) is the diagnostic method of choice. However, it is associated with significant disadvantages, one of them being the risk-prone nature of this procedure necessitating the use of highquality protective equipment by the healthcare professionals. A safer possible alternative could be testing of viral load in blood/serum, as has been seen for other viruses. More than half a year into the pandemic caused by SARS-CoV-2, the question still stands: does this newly found virus cause viraemia? If it does, does its infective nature bring forth numerous practical implications like possibilities of vertical transmission, easier diagnosis, new screening criteria and multiple possible routes of spread? Existing data (given below) show that there is 
unconvincing evidence on the presence of viraemia or viral genetic material in the blood. This has prevented the testing of blood/serum samples for diagnosis of COVID19. An incline to the absence of viraemia has closed doors on its choice as a diagnostic procedure, but even this supposed absence calls for multiple changes in our current practices like testing protocols in neonates of COVID-19 infected mothers. In this article we intend to review the evidence pertaining to the existence of viraemia in COVID-19, its significance and throw light on the numerous new avenues it opens up for a more ingenious and effective response to this pandemic.

\section{VIRAEMIA IN BETA-CORONAVIRUSES}

Respiratory pathogens like adenovirus causing viral pneumonia, influenza type A, avian influenza, and many more have manifested viraemia in the past. Substantial evidence exists over other $\beta$-coronaviruses like SARS coronavirus (2002-2003) and Middle eastern respiratory syndrome (MERS) coronavirus (2012) presenting viraemia, or viral ribonucleic acid (RNA) specifically, in the plasma or serum of patients, during different periods after the onset of symptoms possibly due to viral shedding as shown in Table 1.

\section{Table 1: Evidence of SARS-CoV and MERS-CoV} RNA in blood.

\begin{tabular}{|lll|}
\hline Author & $\begin{array}{l}\text { Serum/blood } \\
\text { samples tested } \\
\text { (n) } \\
\text { age group (adult// } \\
\text { paediatric) } \\
\mathrm{n}=26, \text { adult }\end{array}$ & $\begin{array}{l}\text { Serum } \\
\text { samples } \\
\text { positive for } \\
\text { viral RNA } \\
(\%)\end{array}$ \\
\hline Chan et al & $\mathrm{n}=23$, adult & 78 \\
\hline Ng et al & $\mathrm{n}=50$, adult & 45 \\
\hline Peiris et al & $\mathrm{n}=120$, adult & 28 \\
\hline Lau et al & $\mathrm{n}=50$, adult & 40 \\
\hline Poon et al & $\mathrm{n}=8$, paediatric & 87.5 \\
\hline Eko Ng, et al & $\mathrm{n}=24$, adult & 79 \\
\hline Grant et al & $\mathrm{n}=108$, adult & 33 \\
\hline Corman et al & $\mathrm{n}=21$, adult & 33 \\
\hline Kim et al & & \\
\hline
\end{tabular}

In SARS-CoV, levels of RNAaemia in various studies of varied sample sizes ranged between 28\%-100\%. For Middle eastern respiratory syndrome coronavirus (MERS$\mathrm{CoV}$ ), this was around $33 \%$. Some studies indicated plasma to be a better sample than nasal and throat swabs as nasopharyngeal aspiration is regarded as a risk-prone procedure and shedding of virus in plasma is common in clinically ill patients with SARS-CoV. ${ }^{2}$ Since the onset of the ongoing pandemic, various studies have been conducted to detect viral RNA in serum samples of patients diagnosed with COVID-19. These studies have shown monumental disparities in their results. 10\%-80\% of the samples showed the presence of viral RNA in blood. These studies have been enumerated in Table 2 .

Table 2: Evidence of SARS-CoV-2 RNA in blood.

\begin{tabular}{|lll|}
\hline Author ${ }^{12-19}$ & $\begin{array}{l}\text { Serum/blood } \\
\text { samples tested (n) } \\
\text { age group } \\
\text { (adult/paediatric) }\end{array}$ & $\begin{array}{l}\text { Serum } \\
\text { samples } \\
\text { positive for } \\
\text { viral RNA } \\
(\%)\end{array}$ \\
\hline Huang et al & $\mathrm{n}=41$, adult & 15 \\
\hline Lescure et al & $\mathrm{n}=5$, adult & 20 \\
\hline Duan et al & $\mathrm{n}=10$, adult & 70 \\
\hline Chen et al & $\mathrm{n}=48$, adult & 10.4 \\
\hline $\begin{array}{l}\text { Christensen } \\
\text { et al }\end{array}$ & $\mathrm{n}=5$, adult & 80 \\
\hline $\begin{array}{l}\text { Bermejo - } \\
\text { Martin et al }\end{array}$ & $\mathrm{n}=250$, adult & 51.6 \\
\hline Zheng et al & $\mathrm{n}=96$, adult & 41 \\
\hline Chen et al & $\mathrm{n}=57$, adult & 10.53 \\
\hline
\end{tabular}

Such wide variations in the results indicate that blood is an unreliable standard diagnostic medium for COVID-19. However, viraemia has shown to be a very useful predictor of severity. Studies employing samples of severely ill patients showed higher levels of viraemia. ${ }^{15,17,19}$ Additionally, this was associated with higher mortality. ${ }^{17}$ Thus, even though not for diagnosis, addition of testing of serum sample to the current myriad of laboratory investigations needs to be added for symptomatic patients. However, the above-mentioned evidence of viral RNA in the blood must be taken with a pinch of salt as firstly, evidence of RNAaemia is not equivalent to the presence of the viable infectious virus in the blood. In the limited studies done around this subject, proof of infectiousness has not been found. Secondly, so far, the plasma viral load detected by RT-PCR seems immaterial in comparison to the viral concentration from nasopharyngeal swabs.

\section{PATHOPHYSIOLOGY}

As depicted in figure 1, the symptoms of SARS-CoV-2 have been attributed to various mechanisms like cytokine storm, immune dysregulation, and antibody formation but surprisingly not to viraemia. Per se COVID behaves like a local viral infection. But the absence of the direct pathogenicity by the virus may be the reason for it not eliciting symptoms like rash despite being detected in the blood of some cases. It is imperative that we check the significance of the viraemia in SARS-CoV-2 due to its wide-ranging practical implications. These include blood transfusion, vertical transmission, sexual transmission, modification of current testing guidelines, and the presence of virus particles in other body fluids to name a few. 


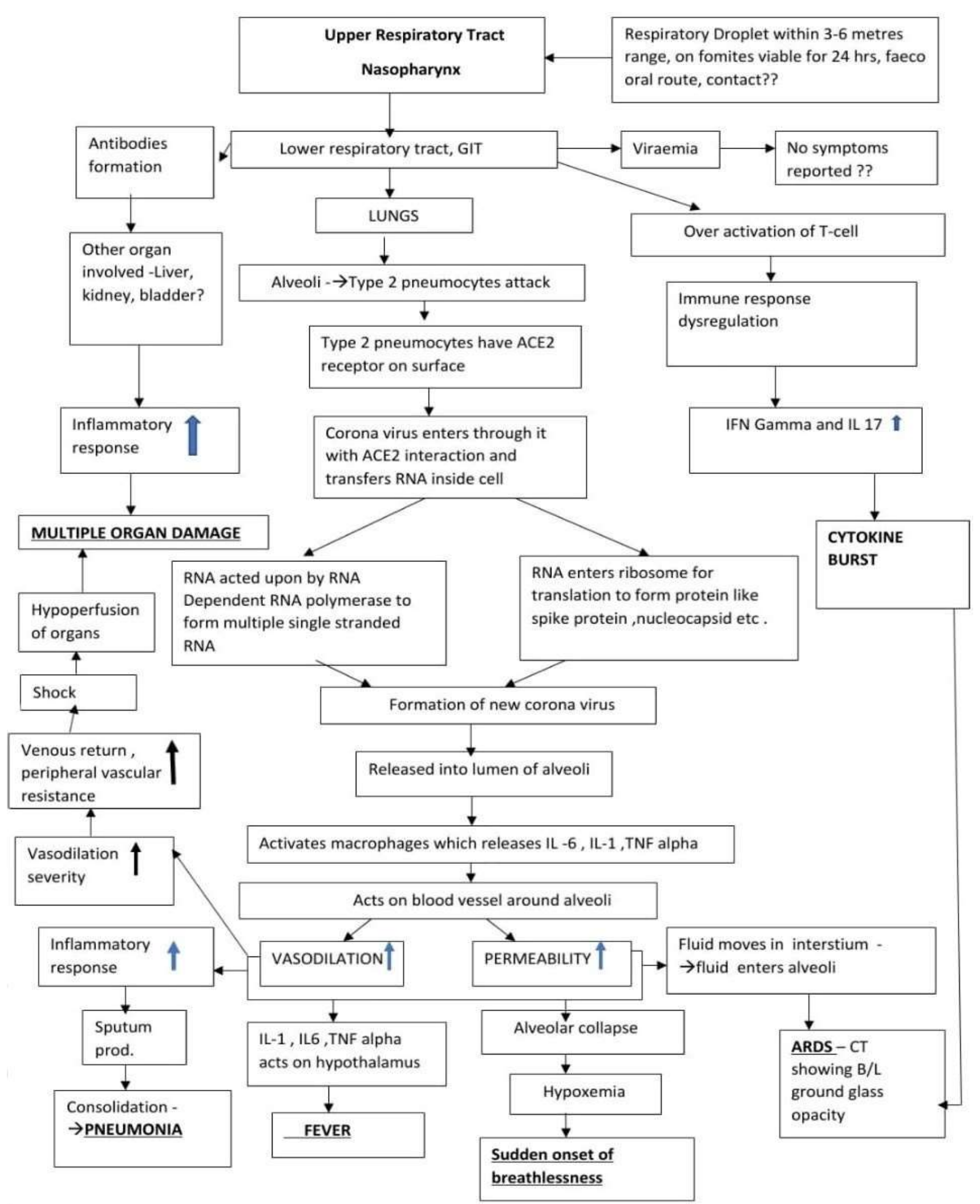

Figure 1: Pathogenesis of SARS CoV -2.

\section{PRACTICAL CLINICAL IMPLICATIONS}

The scientific community has been indecisive about the actual threat that viraemia poses to blood donation. On one hand, till date, there has been no reported case of transfusion-induced infection of SARS-CoV-2. Further, no study on respiratory viruses has shown transmission by blood or blood products. With the existing guidelines, 
anyone with symptoms of active respiratory tract illness is automatically deferred from blood donation. ${ }^{21}$ Screening donors for SARS-CoV RNA was not recommended by WHO and American association of blood banks (AABB) during the 2003 outbreak as the viral load was not considered to be significant enough to pose a risk, and no cases of transfusion-transmission were reported. ${ }^{22,23,24}$ Similarly, blood transfusion during the current pandemic has been deemed fairly safe. With the lack of evidence suggesting transfusion-transmission, AABB, Food drug administration (FDA), and $\mathrm{CDC}$ have not recommended any changes in blood transfusion guidelines specific to the COVID-19 pandemic. $^{22}$

On the other hand, the presence of viral RNA in plasma/ serum of asymptomatic infected persons poses a theoretical risk. Studies following the 2003 outbreak showed evidence of SARS-CoV in plasma of the patients. ${ }^{3-}$ ${ }^{9}$ After the SARS-CoV and MERS-CoV outbreaks, studies investigated pathogen inactivation/reduction technologies (PRTs) to eliminate the potential risk of transmission via transfusion. ${ }^{25-29}$ However, the cost associated with them is a major limitation. WHO's interim guidance regarding COVID-19 states that the risk of transmission through transfusion of blood and components is likely minimal, but several precautionary measures have also been suggested in view of the potential risks. ${ }^{30}$

This urgently necessitates that we explore the infectiousness of the viral particles in the blood further to decide whether to employ radical changes as necessary in the transfusion guidelines. This includes screening to filter out the symptomatic and asymptomatic patients and the widespread installation of PRTs. Currently, with the dearth of evidence of any risk, it would not be wise to turn away donors due to fear of asymptomatic infection. Employing costly PRTs is also unnecessary as the threat of infective particle seems hypothetical at best.

An ample amount of research is proceeding to investigate the vertical transmission of SARS-CoV-2 in the infants of COVID-19 positive mothers. Table 3 gives a summary of the studies done on infants of mothers infected in the third trimester so far. Only one of the studies showed positivity in a meagre $9 \%$ of the newborns, it is to be noted that in these cases the infection was probably not due to perinatal transmission. ${ }^{32}$ No other neonate in any of the other studies was found to be positive. Thus, vertical or perinatal transmission in all probability is non-existent. This suggests the redundancy of the common practice of firstday testing in newborns born to mothers infected in the third trimester. Delivery by caesarean section in the absence of any other indication and testing of umbilical blood need not be done for babies of COVID-19 positive mothers. In view of the severe lack of resources around the world, these practices put a greater strain on the already overworked and understaffed healthcare sector and must be stopped immediately until there is newfound proof.
Table 3: Presence of COVID-19 infection in infants born to COVID-19 positive mothers.

\begin{tabular}{|lll|}
\hline Author & $\begin{array}{l}\text { Sample size } \\
\text { (number of } \\
\text { COVID-19 } \\
\text { positive mothers) }\end{array}$ & $\begin{array}{l}\text { Infants tested } \\
\text { positive }(\%)\end{array}$ \\
\hline Chen et al & 4 & None \\
\hline Zeng et al & 33 & 9 \\
\hline Khan et al & 3 & None \\
\hline $\begin{array}{l}\text { Alzamora et } \\
\text { al }\end{array}$ & 1 & None \\
\hline Zeng et al & 6 & None \\
\hline
\end{tabular}

Little is known about the effects on the foetuses of pregnant women who are infected during conceiving or the first trimester. Past studies on epidemic viruses like Zika virus have shown deadly effects including microcephaly in the foetuses of the mothers infected in the first trimester. ${ }^{36}$ There have been studies showing adverse outcomes in foetuses of SARS-CoV and MERS-CoV positive mothers too, including growth retardation. ${ }^{37}$ In the coming months, as more data is collected on such mothers for SARS-CoV2 , we might be able to add to our current knowledge on the effects on pregnant women and their foetuses, and further implore whether viraemia has a potential role to play in the outcome of these pregnancies. Prospective studies must be carried out from the first-trimester itself instead of solely carrying out studies in the third trimester in infected mothers. Ramped up screening measures since the beginning to detect all possible adverse outcomes in the foetus are necessary. The outcomes of these pregnancies and complications found in the newborn must also be recorded.

The presence of viraemia can also be a gateway for the virus to other bodily secretions. Various studies have shown the definite presence of feco-oral transmission and viral RNA in the faeces. ${ }^{38}$ Although Angiotensin converting enzyme-2 (ACE-2) receptors are expressed in the testis and male reproductive system, no study has shown the presence of the virus in semen in males. ${ }^{39,40}$ As for females, there is a lack of ACE-2 expression in the vaginal and cervical tissues. RT-PCR of vaginal swabs has tested negative in the available studies. ${ }^{41}$ Thus the possibilities of sexual transmission of COVID-19 are highly unlikely. It must be noted here that certain sexual behaviours could possibly still lead to spread of infection due to feco-oral transmission. There have been isolated case reports showing viral RNA in breast milk. ${ }^{42}$ Thus, breastfeeding by a mother having active disease should not be recommended unless it is proven to be non-infective as this puts the baby at great risk. Virus particles have also been isolated from urine, saliva, conjunctival secretions and tears. ${ }^{43-45}$ 


\section{CONCLUSION}

Much research has already been done on the SARS-CoV2 in a short span of time, justifiably so considering the magnitude of the havoc created by it across the globe. The quest to know about its structure, pathogenesis, infectivity, sources of transmission still has major gaps that need to be filled. One such controversial subject has been the presence of viraemia in infected individuals and its implications. There has been substantial evidence to show that viral RNA has been found in the serum of a large proportion of infected individuals. However, to date, there is a paucity of literature that proves infectiousness via blood. This significance if proved would possibly open up newer modes of transmission and a revamp of the current guidelines regarding precautionary measures against the Novel Coronavirus. This could be in the form of newfound proof regarding the existence of vertical transmission and necessary screening protocol in appropriate trimesters. Similarly, its presence in other bodily fluids could open up the possibility of exploring routes of sexual transmission, and protection against the same will have to be advised. All current guidelines regarding blood donation will have to be updated if there is a proven significant risk of this being a potential source of infection. It is necessary that we correlate the levels of viraemia with the presence or absence of symptoms in the individual as well. If present in both symptomatic, as well as asymptomatic individuals, more stringent screening methods, would need to be put into place. This will in turn need greater resource allocation and improved technology as well. We need to explore the possibility of risk to health care workers from sources apart from a droplet infection. If the bloodborne infection is proven, we will have to find out if our current protective equipment would suffice.

As the presence of viraemia is found to be insignificant and negligible to cause any major changes to our current understanding of the virus and its spread, we might consider changing our related strategies. For example, precautionary Caesarean sections need not be performed, newborns of COVID-infected mothers need not be tested on the first day, if all safety precautions are in place. Any changes in blood donation guidelines seem unnecessary and a waste of resources. The ongoing pandemic has been showing a huge rise in the number of worldwide cases with each passing day, and studies throughout the world have shown a decrease in the precautionary habits practiced by individuals and opening up of lockdowns in densely populated countries like India. Thus, it is necessary to do further research on these burning questions as they could play a role in the shaping of the future course of this pandemic.

\section{Funding: No funding sources Conflict of interest: None declared Ethical approval: Not required}

\section{REFERENCES}

1. Likos AM, Kelvin DJ, Cameron CM, Rowe T, Kuehnert MJ, Norris PJ. National Heart, Lung, Blood Institute Retrovirus Epidemiology Donor Study-II (REDS-II). Influenza viremia and the potential for blood-borne transmission. Transfusion. 2007;47(6):1080-8.

2. Grant PR, JA, Tedder RS, Chan PK, Tam JS, Sung JJ. Detection of SARS coronavirus in plasma by realGarson time RT-PCR. New Engl J Med. 2003;349(25):2468-9.

3. Chan KH, Poon LL, Cheng VC, Guan Y, Hung IF, Kong $\mathrm{J}$, et al. Detection of SARS coronavirus in patients with suspected SARS. Emerging infectious diseases. 2004;10(2):294.

4. Ng EK, Hui DS, Chan KA, Hung EC, Chiu RW, Lee $\mathrm{N}$, et al. Quantitative analysis and prognostic implication of SARS coronavirus RNA in the plasma and serum of patients with severe acute respiratory syndrome. Clinical chemistry. 2003;49(12):1976-80.

5. Peiris JS, Lai ST, Poon LL, Guan Y, Yam LY, Lim $\mathrm{W}$ et al. Coronavirus as a possible cause of severe acute respiratory syndrome. The Lancet. 2003;361(9366):1319-25.

6. Tahamtan A, Ardebili A. Real-time RT-PCR in COVID-19 detection: issues affecting the results.

7. Poon LL, Chan KH, Wong OK, Yam WC, Yuen KY, Guan $\mathrm{Y}$ et al. Early diagnosis of SARS coronavirus infection by real time RT-PCR. Journal of Clinical Virology. 2003;28(3):233-8.

8. $\mathrm{Ng}$ EK, Ng PC, Hon KE, Cheng WF, Hung EC, Chan $\mathrm{KA}$, et al. Serial analysis of the plasma concentration of SARS coronavirus RNA in pediatric patients with severe acute respiratory syndrome. Clinical Chemistry. 2003;49(12):2085-8.

9. Grant PR, Garson JA, Tedder RS, Chan PK, Tam JS, Sung JJ. Detection of SARS coronavirus in plasma by real-time RT-PCR. New Engl J Med. 2003;349(25):2468-9.

10. Corman VM, Albarrak AM, Omrani AS, Albarrak MM, Farah ME, Almasri M, et al. Viral shedding and antibody response in 37 patients with Middle East respiratory syndrome coronavirus infection. Clinical Infectious Diseases. 2016;62(4):477-83.

11. Kim SY, Park SJ, Cho SY, Cha RH, Jee HG, Kim G, et al. Viral RNA in blood as indicator of severe outcome in Middle East respiratory syndrome coronavirus infection. Emerging infectious diseases. 2016;22(10):1813.

12. Huang C, Wang Y, Li X, Ren L, Zhao J, Hu Y,et al. Clinical features of patients infected with 2019 novel coronavirus in Wuhan, China. The lancet. 2020;395(10223):497-506.

13. Lescure FX, Bouadma L, Nguyen D, Parisey M, Wicky PH, Behillil S, et al. Clinical and virological data of the first cases of COVID-19 in Europe: a case series. The Lancet Infectious Diseases. 2020;20(6):697-706. 
14. Duan K, Liu B, Li C, Zhang H, Yu T, Qu J, et al. Effectiveness of convalescent plasma therapy in severe COVID-19 patients. Proceedings of the National Academy of Sciences. 2020;117(17):94906.

15. Chen X, Zhao B, Qu Y, Chen Y, Xiong J, Feng Y. Detectable serum severe acute respiratory syndrome Coronavirus 2 viral load (RNAemia) is closely correlated with drastically elevated interleukin 6 level in critically Ill Patients with Coronavirus disease 2019. Clin Infect Dis. 2020.

16. Christensen J, Kumar D, Moinuddin I, Bryson A, Kashi Z, Kimball P, et al. Covid-19 Viremia, Serologies and Clinical Course in a Case Series of Transplant Recipients. In: Transplantation Proceedings. Elsevier. 2020;52(9):2637-41.

17. Bermejo-Martin JF, Gonzalez-Rivera M, Almansa R, Micheloud D, Dominguez-Gil M, Resino S, et al. SARS-CoV-2 RNA viremia is associated with a sepsis-like host response and critical illness in COVID-19. medRxiv. 2020.

18. Zheng S, Fan J, Yu F, Feng B, Lou B, Zou Q, et al. Viral load dynamics and disease severity in patients infected with SARS-CoV-2 in Zhejiang province, China, January-March 2020: retrospective cohort study. bmj. 2020;369.

19. Chen W, Lan Y, Yuan X, Deng X, Li Y, Cai X,et al. Detectable 2019-nCoV viral RNA in blood is a strong indicator for the further clinical severity. Emerging microbes and infections. 2020;9(1):469-73.

20. Jin Y, Yang H, Ji W, Wu W, Chen S, Zhang W, et al. Virology, epidemiology, pathogenesis, and control of COVID-19. Viruses. 2020;12(4):372.

21. World Health Organization. Blood donor selection: guidelines on assessing donor suitability for blood donation. World Health Organization. 2012. Accessed on 07 September 2020.

22. Chang L, Yan Y, Wang L. Coronavirus disease 2019: coronaviruses and blood safety. Transfusion medicine reviews. 2020;34(2):75-80.

23. Cheng PK, Wong DA, Tong LK, Ip SM, Lo AC, Lau $\mathrm{CS}$, et al. Viral shedding patterns of coronavirus in patients with probable severe acute respiratory syndrome. The Lancet. 2004;363(9422):1699-700.

24. Hung IF, Cheng VC, Wu AK, Tang BS, Chan KH, Chu CM, et al. Viral loads in clinical specimens and SARS manifestations. Emerging infectious diseases. 2004;10(9):1550.

25. Eickmann M, Gravemann U, Handke W, Tolksdorf F, Reichenberg S, Müller TH, et al. Inactivation of three emerging viruses-severe acute respiratory syndrome coronavirus, Crimean-Congo haemorrhagic fever virus and Nipah virus-in platelet concentrates by ultraviolet $\mathrm{C}$ light and in plasma by methylene blue plus visible light. Vox Sanguinis. 2020;115(3):146-51.

26. Hashem AM, Hassan AM, Tolah AM, Alsaadi MA, Abunada Q, Damanhouri GA, et al. Amotosalen and ultraviolet A light efficiently inactivate MERS- coronavirus in human platelet concentrates. Transfusion Medicine. 2019;29(6):434-41.

27. Hindawi SI, Hashem AM, Damanhouri GA, ElKafrawy SA, Tolah AM, Hassan AM, et al. Inactivation of Middle East respiratory syndromecoronavirus in human plasma using amotosalen and ultraviolet A light. Transfusion. 2018;58(1):52-9.

28. Eickmann M, Gravemann U, Handke W, Tolksdorf F, Reichenberg S, Müller TH, et al. Inactivation of Ebola virus and Middle East respiratory syndrome coronavirus in platelet concentrates and plasma by ultraviolet $\mathrm{C}$ light and methylene blue plus visible light, respectively. Transfusion. 2018;58(9):2202-7.

29. Darnell ME, Taylor DR. Evaluation of inactivation methods for severe acute respiratory syndrome coronavirus in noncellular blood products. Transfusion. 2006;46(10):1770-7.

30. World Health Organization. Guidance on maintaining a safe and adequate blood supply during the coronavirus disease 2019 (COVID-19) pandemic and on the collection of COVID-19 convalescent plasma: interim guidance, 2020. World Health Organization. 2020. Accessed on 07 September 2020.

31. Chen Y, Peng H, Wang L, Zhao Y, Zeng L, Gao H,et al. Infants born to mothers with a new coronavirus (COVID-19). Frontiers in pediatrics. 2020;8:104.

32. Zeng L, Xia S, Yuan W, Yan K, Xiao F, Shao J, et al. Neonatal early-onset infection with SARS-CoV-2 in neonates born to mothers with COVID-19 in Wuhan, China. JAMA pediatrics. 2020;8:287.

33. Khan S, Peng L, Siddique R, Nabi G, Xue M, Liu J, et al. Impact of COVID-19 infection on pregnancy outcomes and the risk of maternal-to-neonatal intrapartum transmission of COVID-19 during natural birth. Infection Control and Hospital Epidemiology. 2020;41(6):748-50.

34. Alzamora MC, Paredes T, Caceres D, Webb CM, Valdez LM, La Rosa M. Severe COVID-19 during pregnancy and possible vertical transmission. American journal of perinatology. 2020;37(8):861.

35. Zeng H, Xu C, Fan J, Tang Y, Deng Q, Zhang W, et al. Antibodies in infants born to mothers with COVID-19 pneumonia. Jama. 2020;323(18):1848-9.

36. Mlakar J, Korva M, Tul N, Popović M, PoljšakPrijatelj M, Mraz J, et al. Zika virus associated with microcephaly. New England Journal of Medicine. 2016;374(10):951-8.

37. Wong SF, Chow KM, Leung TN, Ng WF, Ng TK, Shek CC, et al. Pregnancy and perinatal outcomes of women with severe acute respiratory syndrome. American journal of obstetrics and gynecology. 2004;191(1):292-7.

38. Gu J, Han B, Wang J. COVID-19: gastrointestinal manifestations and potential fecal-oral transmission. Gastroenterology. 2020;158(6):1518-9.

39. Wang Z, Xu X. scRNA-seq profiling of human testes reveals the presence of the ACE2 receptor, a target for SARS-CoV-2 infection in spermatogonia, Leydig and Sertoli cells. Cells. 2020;9(4):920. 
40. Song C, Wang Y, Li W, Hu B, Chen G, Xia P, et al. Absence of 2019 novel coronavirus in semen and testes of COVID-19 patients. Biology of reproduction. 2020.

41. Qiu L, Liu X, Xiao M, Xie J, Cao W, Liu Z, et al. SARS-CoV-2 is not detectable in the vaginal fluid of women with severe COVID-19 infection. Clinical Infectious Diseases. 2020;71:15.

42. Costa S, Posteraro B, Marchetti S, Tamburrini E, Carducci B, Lanzone A,et al. Excretion of SARSCoV-2 in human breast milk. Clin Micro Infect. 2020;26(10):1430-32.

43. Tian Y, Rong L, Nian W, He Y. gastrointestinal features in COVID-19 and the possibility of faecal transmission. Alimentary pharmacology and therapeutics. 2020;51(9):843-51.

44. Xia J, Tong J, Liu M, Shen Y, Guo D. Evaluation of coronavirus in tears and conjunctival secretions of patients with SARS-CoV-2 infection. Journal of medical virology. 2020;92(6):589-94.

45. Sun J, Zhu A, Li H, Zheng K, Zhuang Z, Chen Z, et al. Isolation of infectious SARS-CoV-2 from urine of a COVID-19 patient. Emerging microbes \& infections. 2020;9(1):991-3.

Cite this article as: Soni A, Arickatt TM, Bhalerao

A, Kondekar S. Covidaemia and its implications. Int J

Contemp Pediatr 2020;7:2409-15. 